\title{
Indian Journal of Pharmaceutical Education and Research: A Scientometric Analysis
}

\author{
Manohar Pathak* \\ GBSSS, Mandoli Extension, Directorate of Education, Govt of NCT Delhi, New Delhi, INDIA.
}

\begin{abstract}
Aim: Scientometric profile of Indian Journal of Pharmaceutical Research has been carried out in this study to highlight and identify the year-wise growth of publication and citation, authorship pattern, prolific organizations, countries, citation profile, international outreach, two year and five year impact factor trend during year 2007-2018. Materials and Methods: Web of science core collection database of Clarivate Analytics was used to retrieve the data using advance search feature. Search field IS $=0019-5464$ was used to extract the data. Document type "Correction" was excluded from the study. Software Vosviewer visualizing scientific landscape version 1.6.11 were used for keyword and co-author network analysis. Results: During 2007-2018 there were 997 papers published in Indian Journal of Pharmaceutical Education and Research with total citation 1714 and $h$-index 14 . KLE University is the most contributing organization in Indian Journal of Pharmaceutical Education and Research. $30.2 \%$ of the articles published in journal are from foreign countries led by Turkey with 93 publications. Among top 10 highly cited papers, 9 articles published in the year 2011. Conclusion: Indian Journal of Pharmaceutical Education and Research has world-wide coverage with 58 countries other than India and citation rate is showing increasing trend. Two year and Five year impact factor is all time high in year 2018 with 0.445 and 0.425 respectively. This paper highlights its significance in coverage of Pharmaceutical Sciences and allied areas hence useful for students, teachers, publisher and Librarian in formulating policies for journal selection.
\end{abstract}

Key words: IJPER, Citation profile, Scientometrics, Pharmaceutics, Journal evaluation.

\section{INTRODUCTION}

Scholarly journals are primary source to disseminate research work in public domain and play significant role in knowledge generation and storage of a particular research area. Selection of journal for publishing research finding for a researcher is a tedious task. There are various journals mushrooming day by day thus, evaluation of journals becomes important to inform and suggest stakeholders in a particular research area. Journals are broadly evaluated by quantitative metrics and subjective methods. There are various methods proposed to evaluate journals depending upon several parameters thus making it complex task to evaluate journals unbiased. Researchers are always in quest for information about journals in their respective fields to publish their manuscript in journal of repute. Journal evaluation is also significant for librarians in order to subscribe best source of information to their libraries. Some parameters for high standard journals are its inclusion in major citation indexing and abstracting databases, double blind peer review system for evaluation of manuscript submitted for publication, recommendation by subject experts, high frequency of citation of published articles by similar journals in their respective fields, readership and usage statistics, rate of submission of articles and their acceptance. Less acceptance percentage are also considered as reputation of academic journals. Bibliometric analysis is one of the most
Submission Date: 10-10-2019; Revision Date: 08-01-2020; Accepted Date: 04-02-20

DOI: 10.5530/ijper.54.2.30 Correspondence: Mr. Manohar Pathak GBSSS, Mandoli Extension, Directorate of Education, Govt of NCT Delhi, Civil Lines-110088, New Delhi, INDIA.

Phone: +91-7906215014 E-mail: manoharpathak@ gmail.com

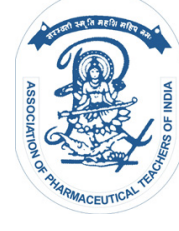

www.ijper.org 
common trend of evaluating journals, organizations and individual researchers reflecting their productivity and impact based on various scientometric indicators. A number of researchers have used bibliometric methods to analyse research journals. Pathak and Bharati ${ }^{1}$ (2018) analysed Indian journal of traditional knowledge to explore the indigenous tribal knowledge and its impact. Nishy et al. ${ }^{2}$ (2012) studied the visibility and impact of Indian Journal of Chemistry section B to investigate its visibility and subject area covered in the journal. Prathap $^{3}$ (2014) explored bibliometric profile of journal current science. Dutt et al. ${ }^{4}$ (2003) investigated journal Scientometrics. Schubert ${ }^{5}$ (2002) analysed first 50 volumes of journal Scientometrics.

Indian Journal of Pharmaceutical Education and Research (IJPER) is the official publication of Association of Pharmaceuticals Teacher of India. IJPER was conceived in 1967 and published quarterly. It publishes research in Pharmaceutical, Pharmacy and allied areas including issues and debates in Pharmaceutical education. IJPER is indexed with Science Citation Index Expanded, a database of Clarivate Analytics from Institute of Scientific Information, Philadelphia, USA under the category Pharmacology Pharmacy and Education Scientific Disciplines since 2007. Elsevier Scimago journal ranking indexes IJPER under Pharmacology, Toxicology and Pharmaceutics and has been ranked 28 out of 74 journals in this category from India with SJR value of 0.169 in Q3. It ranks 14 out of 21 journals in Pharmaceutical sciences indexed by SCI-E among Indian journals. Its current impact factor is 0.425 (JCR 2018). It is indexed by all other reputed citation databases such as Scopus, ABC Chemistry, African Index Medicus, Connect Journals, Geneva Foundation for Medical Education and Research (GFMER), Google Scholar, New Jour-Georgetown University Library USA, Open J Gate, Pharmaceutical Sciences Open Access Resources (PSOAR), Science Central, Ulrichs web, Indian Science Abstracts, Medicinal and Aromatic Plants Abstracts (MAPA), HINARI etc.

The main objective of this paper is to investigate the productivity and impact of IJPER on various scientometric indicators viz. year wise publication growth, most contributing organizations, Authors, Global outreach, highly cited papers, authorship pattern, collaboration, cited and citing journals, Impact factor trend over the years etc.

\section{MATERIALS AND METHODS}

Data for this study was retrieved from Web of Sciencecore collection database of Clarivate Analytics (earlier Thomson Reuters) on $24^{\text {th }}$ Sept 2019. Search was per- formed by using advance search feature of the database for year 2007-2019. This yielded total 1115 documents in six documents types. Web of science provides analyze results feature. By using this feature documents published in year 2019 were excluded from current analysis. Results under Document type "correction" was also excluded from this study as it is repetition of earlier published work. Thus total 997 results obtained and selected for the study. Search technique is as under: IS=0019-5464 Refined by: [excluding] PUBLICATION YEARS: (2019) AND [excluding] DOCUMENT TYPES: (CORRECTION) Timespan: All years. Indexes: SCI-EXPANDED, SSCI, CPCI-S, CPCI-SSH, CCR-EXPANDED, IC.

Results were exported in excel file for further analysis. Authors and organization's name were checked manually and all the variants for same name were normalized to standard name. Software VosViewer visualizing scientific landscape version 1.6.11 were used to map the coauthorship and keyword cluster analysis. Cited journal, citing Journal and Impact factor statistics were downloaded from Incites Journal Citation reports. Indexing and abstracting information was retrieved from Journal's webpage (http://www.ijper.org/content/aboutjournal.asp).

\section{RESULTS AND DISCUSSION}

Indian Journal of Pharmaceutical Education and Research is published since 1967 and till 2018, 52 volumes of the journal has been published including supplementary issues on diversified area of pharmaceutical sciences. During 2007-2018 IJPER published 997 papers, minimum number of papers i.e. 52 was published in year 2010 and 2015 while year 2017 has highest number of published manuscript with 223. Figure 1 depicts the year-wise publication and citations in the epoch. The highest number of cumulative citations have been received by publications published in year 2011 with 435 cites which is $25.37 \%$ of total citations received, followed by year 2017 with 173 citations and year 2012 with 154 citations. IJPER received 1714 citations till the date of data collection that indicates that there are 132 average citations per year and 1.71 citations per item. Overall citations behavior indicates that it is increasing exponentially with 1 citation in year 2007 to 248 citations in year 2019. (Table 1). Citation behavior is in direct correlation with its impact factor. In year 2009 journal impact factor was 0.150 which jumped to 0.425 (JCR 2018). Its five year impact factor is also showing increasing trend (Figure 2). The 997 articles published in journal have been contributed by 2890 authors. analysis of authors reveal that there are 
2388 authors which contributed one article to the journal, 342 authors contributed 2 number of articles, 79 authors contributed 3 number of articles, 46 authors contributed 4 number of articles, 12 authors contributed 5 and 6 number of articles each. Table 2 shows the list of most productive authors with publications 7 or more. Sanjay PN Pai is the most productive author with 10 publications in the journal, followed by Swarnlata Saraf and Nazim Sekeroglu with 9 publications each, Anand Panchakshari Gadad, Kerim Guney, Kamla Pathak and Adhikrao Vyankatrao Yadav contributed 8 articles each, Mahesh Attimarad, Anroop Balachandran Nair, Shailendra Saraf and P V Swamy contributed 7 articles each in IJPER during 2007-2018. Table 3 shows the authorship pattern of published literature in the journal. There are 11 different authorship patterns.
Three author publication is the most prevalent authorship pattern in the journal during period of study with 249 publications, followed by 4 author (211), 2 author (198). Highest number of author in a paper is 11 . There are 47 publications with single author. Table 4 shows the global outreach of Indian Journal of Pharmaceutical Education and Research. Country-wise analysis reflects that there are 59 countries which contributed in the journal. In countries other than India, Turkey is leading the list with 93 publications followed by Malaysia, Republic of China and Saudi Arabia with 43, 27 and 25 publications respectively. Top 10 contributing countries include Iran, Serbia, Pakistan, Egypt and South Korea.

Analysis of contributing organizations indicates that KLE University is the most prolific organization contributing in IJPER with 46 publications followed by

\begin{tabular}{|c|c|c|c|c|c|c|c|c|c|c|c|c|c|c|c|}
\hline Years & Records & 2007 & 2008 & 2009 & 2010 & 2011 & 2012 & 2013 & 2014 & 2015 & 2016 & 2017 & 2018 & 2019 & Total \\
\hline 2007 & 64 & 1 & 4 & 9 & 16 & 13 & 7 & 17 & 11 & 5 & 9 & 5 & 5 & 2 & 104 \\
\hline 2008 & 70 & & 1 & 6 & 8 & 15 & 12 & 16 & 12 & 13 & 12 & 9 & 11 & 5 & 120 \\
\hline 2009 & 56 & & & 1 & 5 & 6 & 7 & 10 & 11 & 8 & 6 & 12 & 7 & 3 & 76 \\
\hline 2010 & 52 & & & & & 12 & 22 & 29 & 34 & 26 & 25 & 13 & 26 & 14 & 201 \\
\hline 2011 & 58 & & & & & 1 & 34 & 41 & 64 & 58 & 64 & 64 & 74 & 35 & 435 \\
\hline 2012 & 56 & & & & & & 2 & 13 & 26 & 23 & 21 & 30 & 28 & 11 & 154 \\
\hline 2013 & 57 & & & & & & & & 9 & 13 & 18 & 17 & 21 & 9 & 87 \\
\hline 2014 & 60 & & & & & & & & 4 & 8 & 25 & 24 & 27 & 19 & 107 \\
\hline 2015 & 52 & & & & & & & & & 5 & 12 & 28 & 27 & 11 & 83 \\
\hline 2016 & 120 & & & & & & & & & & 4 & 35 & 65 & 44 & 148 \\
\hline 2017 & 223 & & & & & & & & & & & 21 & 73 & 79 & 173 \\
\hline 2018 & 129 & & & & & & & & & & & & 10 & 16 & 26 \\
\hline Total & 997 & 1 & 5 & 16 & 29 & 47 & 84 & 126 & 171 & 159 & 196 & 258 & 374 & 248 & 1714 \\
\hline
\end{tabular}

Table 2: Most Prolific Authors.

\begin{tabular}{|c|c|c|}
\hline SI. No. & Author & $\begin{array}{c}\text { No. of } \\
\text { Publication }\end{array}$ \\
\hline 1. & Pai, Sanjay PN & 10 \\
\hline 2. & Saraf, Swarnlata & 9 \\
\hline 3. & Sekeroglu, Nazim & 9 \\
\hline 4. & Gadad, Anand Panchakshari & 8 \\
\hline 5. & Guney, Kerim & 8 \\
\hline 6. & Pathak, Kamla & 8 \\
\hline 7. & Yadav, Adhikrao Vyankatrao & 8 \\
\hline 8. & Attimarad, Mahesh & 7 \\
\hline 9. & Nair, Anroop Balachandran & 7 \\
\hline 10. & Saraf, Shailendra & 7 \\
\hline 11. & Swamy, P V & 7 \\
\hline
\end{tabular}

Table 3: Authorship Pattern in IJPER.

\begin{tabular}{|c|c|}
\hline No of Authors & Publication \\
\hline 3 & 249 \\
\hline 4 & 211 \\
\hline 2 & 198 \\
\hline 5 & 164 \\
\hline 6 & 76 \\
\hline 7 & 32 \\
\hline 10 & 6 \\
\hline 8 & 9 \\
\hline 1 & 47 \\
\hline 9 & 4 \\
\hline 11 & 1 \\
\hline
\end{tabular}




\section{Table 4: Countries Contributing in IJPER.}

\begin{tabular}{|c|c|c|c|}
\hline SI. No. & Countries/Regions & Records & $\%$ age \\
\hline 1. & India & 695 & 69.709 \\
\hline 2. & Turkey & 93 & 9.328 \\
\hline 3. & Malaysia & 43 & 4.313 \\
\hline 4. & Peoples Republic of China & 27 & 2.708 \\
\hline 5. & Saudi Arabia & 25 & 2.508 \\
\hline 6. & Iran & 17 & 1.705 \\
\hline 7. & Serbia & 13 & 1.304 \\
\hline 8. & Pakistan & 12 & 1.204 \\
\hline 9. & Egypt & 10 & 1.003 \\
\hline 10. & South Korea & 10 & 1.003 \\
\hline
\end{tabular}

\begin{tabular}{|c|c|c|}
\hline SI. No. & Organizations & Publication \\
\hline 1. & KLE University, Belgaum, Karnataka & 46 \\
\hline 2. & $\begin{array}{l}\text { JSS College of Pharmacy, Ooty, Tamil } \\
\text { Nadu }\end{array}$ & 34 \\
\hline 3. & Kastamonu University, Turkey & 23 \\
\hline 4. & Bharati Vidyapeeth, Pune, Maharashtra & 21 \\
\hline 5. & Ordu University, Turkey & 18 \\
\hline 6. & Govt. College of Pharmacy, Banglore & 17 \\
\hline 7. & $\begin{array}{c}\text { HKE Society College of Pharmacy, } \\
\text { Gulbarga, Karnataka }\end{array}$ & 17 \\
\hline 8. & $\begin{array}{l}\text { Manipal College of Pharmaceutical } \\
\text { Sciences, Manipal, Karnataka }\end{array}$ & 17 \\
\hline 9. & Universiti Teknologi Mara, Malaysia & 17 \\
\hline 10. & University of Belgrade, Serbia & 14 \\
\hline
\end{tabular}

\begin{tabular}{|c|c|}
\hline \multicolumn{2}{|c|}{ Table 6: Citation of articles. } \\
\hline Citation & Papers \\
\hline 0 & 483 \\
\hline $1-5$ & 450 \\
\hline $06-10$ & 44 \\
\hline $11-20$ & 13 \\
\hline $21-30$ & 5 \\
\hline $31-70$ & 2 \\
\hline
\end{tabular}

JSS College of Pharmacy with 34 publications. In the top 10 organizations four are from foreign countries. Kastamonu University is leading the list of organizations among foreign countries with 23 publications followed by Ordu University, Univ Tehnol Mara and Belgrade University with 18, 17 and 14 publications respectively

\begin{tabular}{|c|c|c|c|}
\hline \multicolumn{4}{|c|}{ Table 7: High Impact cited Journal in IJPER. } \\
\hline SI. No. & $\begin{array}{c}\text { IF (JCR } \\
\text { 2018) }\end{array}$ & Journals & Citation \\
\hline 1. & 223.679 & $\begin{array}{c}\text { CA-Cancer Journal for } \\
\text { Clinicians }\end{array}$ & 3 \\
\hline 2. & 70.67 & $\begin{array}{c}\text { New England Journal of } \\
\text { Medicine }\end{array}$ & 10 \\
\hline 3. & 59.102 & Lancet & 7 \\
\hline 4. & 57.618 & $\begin{array}{c}\text { Nature Review Drug } \\
\text { Discovery }\end{array}$ & 5 \\
\hline 5. & 51.848 & Nature Review Cancer & 4 \\
\hline 6. & 51.273 & $\begin{array}{c}\text { Jama-Journal of American } \\
\text { Medical Association }\end{array}$ & 3 \\
\hline 7. & 43.07 & Nature & 8 \\
\hline 8. & 41.037 & Science & 9 \\
\hline 9. & 36.216 & Cell & 5 \\
\hline 10. & 27.604 & BMJ-British Medical Journal & 4 \\
\hline
\end{tabular}

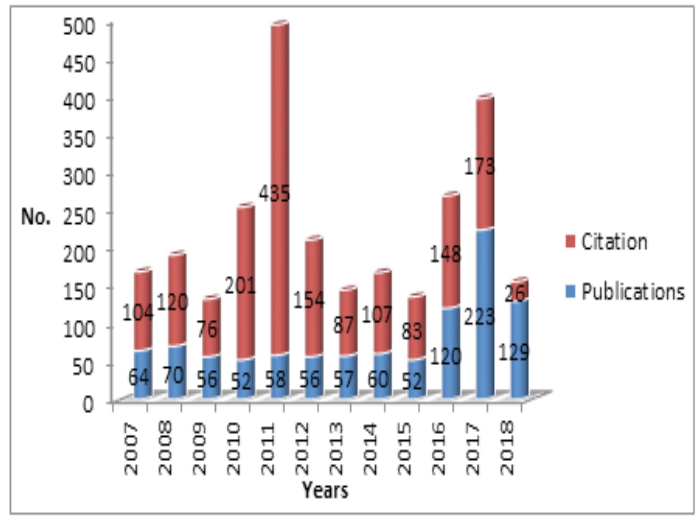

Figure 1: Publication and Citation trend.

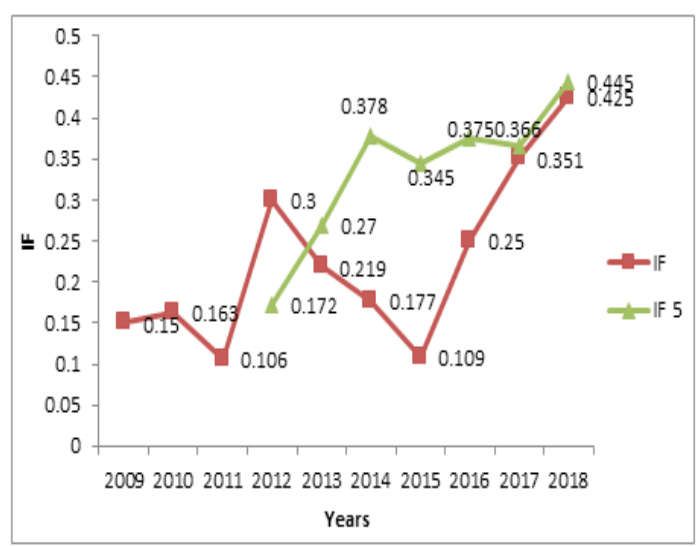

Figure 2: Impact Factor Trend of IJPER.

(Table 5). There are total 824 organizations which have contributed in this journal.

The co-authorship network analysis reveals that there are 8 cluster of co-authorship with 55 items and 138 links (Figure 3). Cluster 1 consists of 9 items, cluster 2,3 and 4 each with 8 items, cluster 5 and 6 consists 6 item 
each and cluster 7 and 8 comprising of 5 items. Similarly Co-occurrence analysis of keywords depicts that there are total 3288 author keywords with antioxidant as most frequent keywords with 28 occurrences. The keyword network distributed in 82 clusters with 2569 items and 7734 links. Cluster 1 consists of 69 items followed cluster 2 with 63 items, cluster 3 and 4 each with 60 items. (Figure 4)

\begin{tabular}{|c|c|c|c|}
\hline $\begin{array}{l}\text { SI. } \\
\text { No. }\end{array}$ & $\begin{array}{l}\text { IF (JCR } \\
\text { 2018) }\end{array}$ & Journals & Citation \\
\hline 1. & 8.243 & $\begin{array}{l}\text { Advances in Colloid and } \\
\text { Interface Science }\end{array}$ & 2 \\
\hline 2. & 5.839 & Food Hydrocolloids & 2 \\
\hline 3. & 4.784 & $\begin{array}{l}\text { International Journal of Biological } \\
\text { Macromolecules }\end{array}$ & 7 \\
\hline 4. & 4.773 & Pharmaceutics & 3 \\
\hline 5. & 4.471 & $\begin{array}{l}\text { International Journal of } \\
\text { Nanomedicine }\end{array}$ & 4 \\
\hline 6. & 4.213 & $\begin{array}{l}\text { International Journal of } \\
\text { Pharmaceutics }\end{array}$ & 2 \\
\hline 7. & 4.191 & Industrial Crops and Products & 4 \\
\hline 8. & 4.011 & Scientific Reports-UK & 2 \\
\hline
\end{tabular}

Out of 997 articles published in Indian Journal of Pharmaceutical Education and Research, 514 articles have received citation. Highest number of citations received is 68. There are two articles having citation between 31-70 5 articles have received citations between 21-30, 13 articles have citation range 11-20, 44 articles have citations between 6-10 and 450 articles have citations between 1-5 (Table 6). Total 3604 number of journals has been cited by IJPER. Table 7 enlists high impact
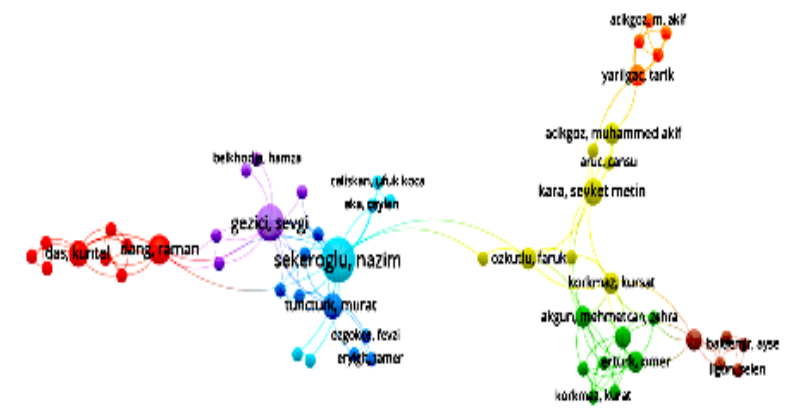

Mosnewer

Figure 3: Co-Authorship Network Mapping.

\begin{tabular}{|c|c|c|c|c|c|c|}
\hline SI. No. & Title & Authors & $\begin{array}{l}\text { Vol. and } \\
\text { Issue }\end{array}$ & Year & Page & Cites \\
\hline 1. & $\begin{array}{c}\text { Recent Investigations of Plant Based Natural } \\
\text { Gums, Mucilages and Resins in Novel Drug } \\
\text { Delivery Systems }\end{array}$ & $\begin{array}{l}\text { Avachat, Amelia M.; Dash, Rakesh R.; } \\
\text { Shrotriya, Shilpa N. }\end{array}$ & $45(1)$ & 2011 & $86-99$ & 68 \\
\hline 2. & $\begin{array}{c}\text { Polymeric Micelles: General Considerations } \\
\text { and their Applications }\end{array}$ & $\begin{array}{l}\text { Mourya, V. K.; Inamdar, Nazma; Nawale, } \\
\text { R. B.; Kulthe, S. S. }\end{array}$ & $45(2)$ & 2011 & $\begin{array}{l}128- \\
138\end{array}$ & 47 \\
\hline 3. & $\begin{array}{l}\text { Evaluation of the Kinetics and Mechanism } \\
\text { of Drug Release from Econazole nitrate } \\
\text { Nanosponge Loaded Carbapol Hydrogel }\end{array}$ & $\begin{array}{c}\text { Sharma, Renuka; Walker, Roderick B.; } \\
\text { Pathak, Kamla }\end{array}$ & $45(1)$ & 2011 & $25-31$ & 30 \\
\hline 4. & Stability Aspects of Liposomes & $\begin{array}{c}\text { Yadav, A., V; Murthy, M. S.; Shete, A. S.; } \\
\text { Sakhare, Sfurti }\end{array}$ & $45(4)$ & 2011 & $\begin{array}{c}402- \\
413\end{array}$ & 29 \\
\hline 5. & $\begin{array}{l}\text { Formulation and Characterization of Rapidly } \\
\text { Dissolving Films of Cetirizine hydrochloride } \\
\text { using Pullulan as a Film Forming Agent }\end{array}$ & Mishra, Renuka; Amin, Avani & $45(1)$ & 2011 & $71-77$ & 28 \\
\hline 6. & Microemulsions For Topical Use-A Review & $\begin{array}{l}\text { Grampurohit, Nirmala; Ravikumar, } \\
\text { Padmini; Mallya, Rashmi }\end{array}$ & $45(1)$ & 2011 & $\begin{array}{l}100- \\
107\end{array}$ & 25 \\
\hline 7. & $\begin{array}{l}\text { Formulation and Evaluation of Topical } \\
\text { Liposomal Gel for Fluconazole }\end{array}$ & $\begin{array}{l}\text { Mitkari, B. V.; Korde, S. A.; Mahadik, K. } \\
\text { R.; Kokare, C. R. }\end{array}$ & $44(4)$ & 2010 & $\begin{array}{l}324- \\
333\end{array}$ & 24 \\
\hline 8. & $\begin{array}{l}\text { Potential of Novel Drug Delivery Systems for } \\
\text { Herbal Drugs }\end{array}$ & $\begin{array}{l}\text { Goyal, Ashwani; Kumar, Sandeep; } \\
\text { Nagpal, Manju; Singh, Inderbir; Arora, } \\
\text { Sandeep }\end{array}$ & $45(3)$ & 2011 & $\begin{array}{l}225- \\
235\end{array}$ & 18 \\
\hline 9. & $\begin{array}{l}\text { Formulation and Evaluation of pH-triggered in } \\
\text { situ Gelling System of Levofloxacin }\end{array}$ & $\begin{array}{c}\text { Mohanambal, E.; Arun, K.; Sathali, Abdul } \\
\text { Hasan A. }\end{array}$ & $45(1)$ & 2011 & $58-64$ & 18 \\
\hline 10. & $\begin{array}{l}\text { Radical Scavenging and Antioxidant Activity } \\
\text { of Ethanolic Extract of Mollugo nudicaulis by } \\
\text { in vitro Assays }\end{array}$ & $\begin{array}{l}\text { Rajamanikandan, S.; Sindhu, } \\
\text { T.; Durgapriya, D.; Sophia, D.; } \\
\text { Ragavendran, P.; Gopalakrishnan, V. K. }\end{array}$ & $45(4)$ & 2011 & $\begin{array}{l}310- \\
316\end{array}$ & 17 \\
\hline
\end{tabular}




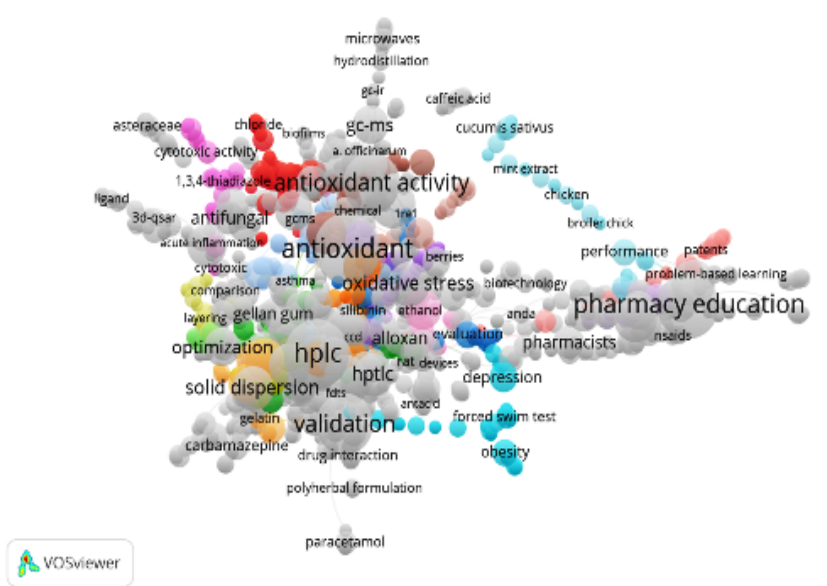

Figure 4: Keyword Network in IJPER.

citing journals. CA-Cancer Journal of Clinicians having impact factor 223.67 have been cited twice in this journal, followed by New England Journal of Medicine (70.67), Lancet (59.102), Nature Review Drug Discovery (57.618), Nature Review Cancer (51.848), JAMA-Journal of American Medical Association (51.273), Nature (43.07) and Science (41.037). There are total 69 journals in which IJPER has been cited. Among high impact journals in which published article of IJPER has been cited includes Advanced Colloid Interface (8.243), Food bydrocolloid (5.839), International Journal of Biological Macromolecule (4.784), Pharmacentics (4.773) (Table 8).

Table 9 highlights the top 10 highly cited articles in IJPER. Out of 10 top highly cited article 9 have been published in year 2011 and one article published in 2010. This reveals that article published in year is the most impactful. The most cited work is entitled Recent Investigations of Plant Based Natural Gums, Mucilages and Resins in Novel Drug Delivery Systems by Avachat et al. published in 2011 with 68 citations followed by Polymeric Micelles: General Considerations and their Applications by Mourya et al. with 47 citation, Evaluation of the Kinetics and Mechanism of Drug Release from Econazole nitrate Nanosponge Loaded Carbapol Hydrogel by Sharma et al. and Stability Aspects of Liposomes by Yadav et al.

\section{CONCLUSION}

It can be concluded that Indian Journal of Pharmaceutical Education and Research is one of the significant journal in the field of Pharmaceutical research. This study will be useful to teachers, students, Publishers and Librarians in evaluating research and status of the journal. This may also be useful for policy and planning to focus on pharmaceutical research and explore the unidentified and uncovered area in Pharmaceutical Sciences and Pharmacy.

\section{ACKNOWLEDGEMENT}

Author is thankful to Director, CSIR-NISCAIR and Mr. R S Jayasomu for giving access to Web of Science.

\section{CONFLICT OF INTEREST}

The author declare no conflict of interest.

\section{ABBREVIATIONS}

IJPER: Indian Journal of Pharmaceutical Education and Research; SCI-E: Science citation Index Expanded; JCR: Journal Citation Report; IF: Impact Factor.

\section{REFERENCES}

1. Pathak M, Bharati KA. Growing visibility and impact of Indian Journal of Traditional Knowledge. Indian Journal of Traditional Knowledge. 2018;17(3):407-13.

2. Nishy P, Parvatharajan P, Prathap G. Visibility and impact of the Indian Journal of Chemistry, Section B during 2005-2009 using scientometric Techniques. Indian Journal of Chemistry Section B. 2012;51B(1):269-84.

3. Prathap G. A bibliometric profile of Current Science. Current Science. 2014;106(7):958-63.

4. Dutt B, Garg KC, Bali A. Scientometrics of the international journal Scientometrics. Scientometrics. 2003;56(1):81-93.

5. Schubert A. The web of scientometrics: A statistical overview of the first 50 volumes of the journal. Scientometrics. 2002;53(1):3-20.

\section{SUMMARY}

Pictorial abstract depicts the publication and citations during 2007-2018 as well as 2-year and five year impact factor trend of Indian Journal of Pharmaceutical Education and Research. In addition it also highlights the cluster of author keyword network and coauthorship network. 
PICTORIAL ABSTRACT

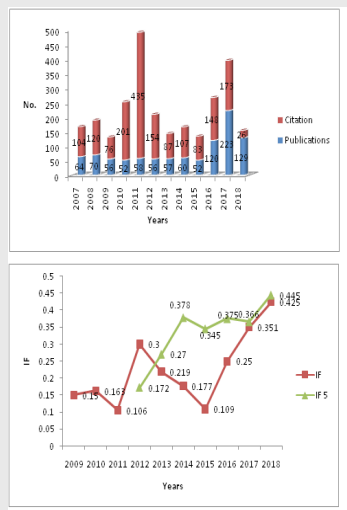

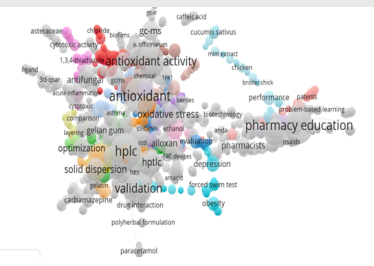
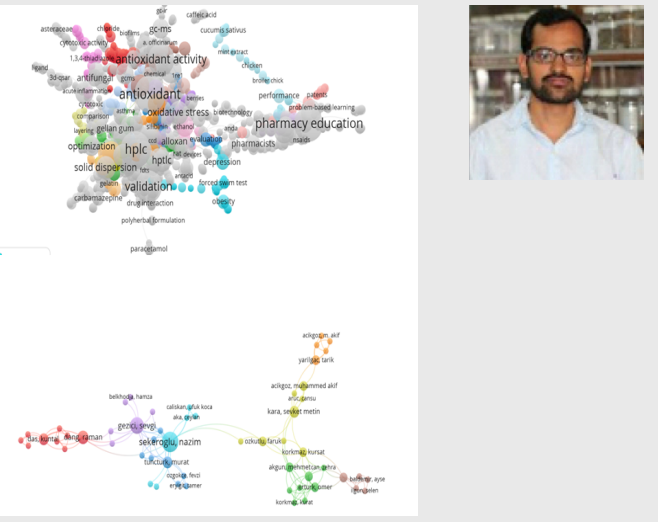

About Authors

Manohar Pathak, is a M.Sc. (Botany), MLIS working with Directorate of Education. Govt of NCT Delhi. His research area focuses on Scientometrics and Informetrics, citation analysis and quantitative studies of science.

Cite this article: Pathak M. Indian Journal of Pharmaceutical Education and Research: A Scientometric Analysis. Indian J of Pharmaceutical Education and Research. 2020;54(2):264-70. 